\title{
Perbandingan efektivitas pendidikan kesehatan gigi menggunakan media video dan flip chart terhadap peningkatan pengetahuan kesehatan gigi dan mulut anak
}

\author{
${ }^{1}$ Zakarias R. Kantohe \\ ${ }^{2}$ Vonny N. S. Wowor \\ ${ }^{2}$ Paulina N. Gunawan \\ ${ }^{1}$ Kandidat Skripsi Program Studi Pendidikan Dokter Gigi Fakultas Kedokteran \\ ${ }^{2}$ Program Studi Pendidikan Dokter Gigi Fakultas Kedokteran \\ Universitas Sam Ratulangi Manado \\ Email: zakariaskantohe@ rocketmail.com
}

\begin{abstract}
Currently, the oral health of children in Indonesia is still a problem dominated by caries and periodontal disease. A highly influential factor to these two diseases is behavior. One way to change that behavior is by intervening through education to improve children knowledge by using media or tools. This study aimed to compare the effectiveness of dental health education using video media and flip chart in increasing children knowledge about oral health. This was a quasi experiment with a non equivalent control group design. Samples were students of SDN Kolongan aged 10-11 years old obtained by using total sampling method and were divided into two treatment groups: video media and flip chart. This study used the Mann-Whitney hypothesis test with a confidence level of 95\% ( $p<0.05)$. The results showed that the $\mathrm{p}$-value of dental health education influence using video media and flip chart to the improvement of oral health knowledge of children was 0.000 for each media. The statistical test comparing the effectiveness of dental health education using both media showed a p-value of 0.007. Conclusion: Dental health education using video and flip chart media improved effectively the oral health knowledge of students. Moreover, dental health education using video media was more effective in improving the oral health knowledge of students than using flip chart media.
\end{abstract}

Keywords: dental health education, video media, flip chart media, children knowledge

\begin{abstract}
Abstrak: Saat ini kesehatan gigi dan mulut anak di Indonesia masih menjadi masalah yang didominasi oleh penyakit karies gigi serta periodontal. Faktor yang sangat bepengaruh pada kedua penyakit ini yaitu faktor perilaku. Salah satu cara untuk merubah perilaku yakni dengan melakukan intervensi lewat pendidikan untuk meningkatkan pengetahuan anak. Pemberian pendidikan kesehatan gigi dan mulut (PKG) pada anak akan lebih efektif dan optimal bila menggunakan media atau alat bantu. Penelitian ini bertujuan untuk mengetahui perbandingan efektivitas PKG menggunakan media video dan flip chart terhadap peningkatan pengetahuan kesehatan gigi dan mulut anak. Jenis penelitian ialah quasi experiment dengan rancangan non equivalent control group. Sampel yaitu siswa SDN Kolongan yang berusia 10-11 tahun. Teknik pengambilan sampel menggunakan metode total sampling. Sampel dibagi menjadi dua kelompok perlakuan yaitu kelompok yang menggunakan media video dan kelompok yang menggunakan media flip chart. Penelitian ini menggunakan uji hipotesis Mann-Whitney dengan tingkat kepercayaan 95\% ( $<<0,05)$. Hasil penelitian menunjukkan bahwa PKG menggunakan media video dan flip chart terhadap peningkatan pengetahuan kesehatan gigi dan mulut anak masingmasing dengan nilai $\mathrm{p}=0,000$. Hasil uji statistik perbandingan efektivitas PKG dengan menggunakan kedua media tersebut mendapatkan nilai $\mathrm{p}=0,007$. Simpulan: PKG menggunakan media video dan flip chart efektif terhadap peningkatan pengetahuan kesehatan gigi dan mulut anak. PKG menggunakan media video lebih efektif dalam meningkatkan pengetahuan kesehatan gigi dan mulut anak dibandingkan menggunakan media flip chart.
\end{abstract}

Kata kunci: PKG, media video, media flip chart, pengetahuan anak 
Kesehatan gigi dan mulut merupakan hal yang penting dalam kehidupan setiap individu termasuk pada anak, karena gigi dan gusi yang rusak dan tidak dirawat akan menyebabkan rasa sakit, gangguan pengunyahan, dan dapat mengganggu kesehatan tubuh lainnya. ${ }^{1}$ Masalah gigi dan mulut pada anak dapat juga berpengaruh pada pertumbuhan dan perkembangan anak. Kondisi kesehatan gigi susu akan turut menentukan pertumbuhan gigi tetap anak. Di samping itu anak-anak merupakan kelompok umur yang rentan terhadap penyakit. Anak yang memiliki masalah pada kesehatan gigi dan mulutnya dapat terganggu kualitas hidupnya, padahal anak merupakan aset bangsa untuk pembangunan di masa yang akan datang. ${ }^{2}$

Saat ini kesehatan gigi dan mulut penduduk Indonesia masih menjadi masalah. Hal ini dapat dilihat dari terus meningkatnya masalah gigi dan mulut di Indonesia. Berdasarkan data Riset Kesehatan Dasar (Riskesdas) Tahun 2007 dan 2013, persentase penduduk Indonesia yang mempunyai masalah gigi dan mulut meningkat dari $23,2 \%$ menjadi $25,9 \%$, untuk kelompok umur 5-9 tahun dari 21,6\% menjadi $28,9 \%$ dan untuk kelompok umur 10-14 tahun dari 20,6\% menjadi $25,2 \%{ }^{3}$ Penyakit karies gigi dan penyakit periodontal merupakan masalah gigi dan mulut yang paling sering terjadi pada anak. Faktor yang sangat bepengaruh pada kedua penyakit ini yaitu faktor perilaku.

Berdasarkan data dari Riskesdas Tahun 2007 dan 2013, persentase perilaku penduduk umur 10 tahun ke atas yang menyikat gigi dengan benar dari $7,3 \%$ di tahun 2007 menurun menjadi 2,3\% di tahun 2013. ${ }^{3}$ Hal ini menjadi masalah, karena salah satu cara pencegahan yang efektif terhadap terjadinya penyakit karies dan periodontal yakni melalui tindakan menyikat gigi. Terbentuknya perilaku menyikat gigi individu yang benar didasari oleh pengetahuan individu yang diperoleh antara lain melalui pendidikan. ${ }^{4}$ Demikian halnya untuk mengubah perilaku yang tidak benar menjadi perilaku yang benar juga intervensinya lewat pendidikan.
Pendidikan kesehatan gigi dan mulut (PKG) merupakan suatu proses pendidikan yang timbul atas dasar kebutuhan kesehatan gigi dan mulut yang bertujuan untuk menghasilkan kesehatan gigi dan mulut yang baik dan meningkatkan taraf hidup. Dalam proses pendidikan termasuk pendidikan kesehatan gigi dan mulut, individu memperoleh pengalaman atau pengetahuan melalui berbagai media pendidikan. Menurut Edgar Dale yang digambarkan lewat 'Kerucut Pengalaman Dale,' proses pendidikan dengan melibatkan lebih banyak indera akan lebih mudah diterima dan diingat oleh para sasaran pendidikan. ${ }^{5}$ Pemberian pendidikan kesehatan pun akan lebih efektif dan hasilnya optimal ketika menggunakan metode dan media pendidikan kesehatan yang tepat dan melibatkan lebih banyak indera. Penelitian $\operatorname{Tan}^{6}$ tahun 2010 menunjukkan bahwa penyuluhan menggunakan alat peraga gigi lebih efektif dalam meningkatkan pengetahuan daripada penyuluhan menggunakan media video, karena melibatkan lebih banyak indera.

Penelitian ini bertujuan untuk mendapatkan perbandingan efektivitas pendidikan kesehatan gigi menggunakan media video dan flip chart terhadap peningkatan pengetahuan kesehatan gigi dan mulut (PKG) anak di SDN Kolongan. Penyakit karies banyak dialami dan masih menjadi masalah bagi kesehatan gigi dan mulut anak-anak di desa tersebut dan selama ini belum pernah dilakukan penelitian ataupun penyuluhan tentang kesehatan gigi dan mulut pada anak-anak di desa Kolongan.

\section{BAHAN DAN METODE PENELITIAN}

Jenis penelitian ini ialah quasi experiment dengan rancangan non equivalent control group. Penelitian dilaksanakan di SDN Kolongan pada bulan Februari-Agustus 2016. Sampel dalam penelitian ini yaitu siswa SDN Kolongan yang berusia 10-11 tahun berjumlah 64 siswa yang telah memenuhi kriteria inklusi. Pengambilan sampel menggunakan metode total sampling. Sampel kemudian dibagi 
menjadi dua kelompok dengan cara undian, sehingga didapatkan 32 sampel pada kelompok perlakuan PKG menggunakan media video dan 32 sampel pada kelompok perlakuan PKG menggunakan media flip chart. Instrumen dalam penelitian ini yaitu kuesioner. Pengolahan dan analisis data menggunakan SPSS versi 16 yang disajikan dalam bentuk tabel.

\section{HASIL PENELITIAN}

Karakteristik respoden dalam penelitian ini dapat dilihat pada Tabel 1 dan 2 .

Tabel 1. Distribusi frekuensi responden berdasarkan jenis kelamin

\begin{tabular}{ccccc}
\hline \multirow{2}{*}{$\begin{array}{c}\text { Jenis } \\
\text { kelamin }\end{array}$} & \multicolumn{2}{c}{ Media Video } & \multicolumn{2}{c}{$\begin{array}{c}\text { Media } \text { Flip } \\
\text { chart }\end{array}$} \\
\cline { 2 - 5 } & \multicolumn{2}{c}{ Frekuensi } & \multicolumn{2}{c}{ Frekuensi } \\
& \multicolumn{2}{c}{ Persentase (\%) } & \multicolumn{2}{c}{ Persentase (\%) } \\
\hline Laki-Laki & 14 & 43,8 & 13 & 40,6 \\
Perempuan & 18 & 56,2 & 19 & 59,4 \\
Total & 32 & 100 & 32 & 100 \\
\hline
\end{tabular}

Tabel 2. Distribusi frekuensi responden berdasarkan usia

\begin{tabular}{|c|c|c|c|c|}
\hline \multirow{2}{*}{$\begin{array}{c}\text { Usia } \\
\text { (tahun) }\end{array}$} & \multicolumn{2}{|c|}{ Media video } & \multicolumn{2}{|c|}{ Media flip chart } \\
\hline & $\begin{array}{r}F \\
\text { Pers }\end{array}$ & $\begin{array}{l}\text { ensi } \\
\text { se }(\%)\end{array}$ & $\begin{array}{r}F \\
\text { Pers }\end{array}$ & $\begin{array}{l}\text { nsi } \\
\text { e }(\%)\end{array}$ \\
\hline 10 & 18 & 56,2 & 18 & 56,2 \\
\hline 11 & 14 & 43,8 & 14 & 43,8 \\
\hline Total & 32 & 100 & 32 & 100 \\
\hline
\end{tabular}

Tabel 3. Hasil pengukuran tingkat pengetahuan anak

\begin{tabular}{ccccc}
\hline \multirow{2}{*}{$\begin{array}{c}\text { Item } \\
\text { pertanyaan }\end{array}$} & Media video & \multicolumn{2}{c}{$\begin{array}{c}\text { Media flip } \\
\text { chart }\end{array}$} \\
\cline { 2 - 5 } & \multicolumn{2}{c}{$\begin{array}{c}\text { Pre-test } \\
\text { Post-test }\end{array}$} & \multicolumn{2}{c}{$\begin{array}{c}\text { Pre-test } \\
\text { Post-test }\end{array}$} \\
\hline 1 & 64 & 64 & 64 & 64 \\
2 & 60 & 63 & 56 & 62 \\
3 & 63 & 63 & 63 & 64 \\
4 & 64 & 64 & 61 & 64 \\
5 & 62 & 63 & 58 & 64 \\
6 & 59 & 64 & 55 & 64 \\
7 & 34 & 54 & 36 & 44 \\
8 & 38 & 48 & 34 & 38 \\
9 & 38 & 46 & 37 & 47 \\
10 & 33 & 52 & 39 & 41 \\
\hline Total skor & 515 & 581 & 503 & 552 \\
Selisih & \multicolumn{2}{c}{66} & \multicolumn{3}{c}{49} \\
\hline
\end{tabular}

Tabel 4. Uji normalitas Shapiro-Wilk media video

\begin{tabular}{ccccc}
\hline & Kelompok & Statistic & Df & Sig. \\
\hline \multirow{2}{*}{ Hasil } & Pre-test &, 894 & 32 &, 004 \\
& Post-test &, 882 & 32 &, 002 \\
\hline
\end{tabular}

Tabel 5. Uji normalitas Shapiro-Wilk media flip chart

\begin{tabular}{ccccc}
\hline & Kelompok & Statistic & Df & Sig. \\
\hline \multirow{2}{*}{ Hasil } & Pre-test &, 900 & 32 &, 006 \\
& Post-test &, 876 & 32 &, 002 \\
\hline
\end{tabular}

Tabel 6. Uji Wilcoxon media video

\begin{tabular}{ccccc}
\hline Kelompok & n & Mean & Std & Sig. \\
\hline Pre-test & 32 & 80,47 & 4,465 & \multirow{2}{*}{000} \\
Post-test & 32 & 90,78 & 5,695 & \\
\hline
\end{tabular}

Tabel 7. Uji Wilcoxon media flip chart

\begin{tabular}{ccccc}
\hline Kelompok & $\mathbf{n}$ & Mean & Std & Sig. \\
\hline Pre-test & 32 & 78,59 & 5,713 & \multirow{2}{*}{000} \\
Post-test & 32 & 86,25 & 4,579 & \\
\hline
\end{tabular}

Tabel 8. Uji Mann-Whitney antara media video dan media flip chart

\begin{tabular}{ccccc}
\hline Media & n & Mean & Df & Sig. \\
\hline Video & 32 & 38,12 & \multirow{2}{*}{64} & \multirow{2}{*}{007} \\
Flip chart & 32 & 26,88 & & \\
\hline
\end{tabular}

\section{BAHASAN}

Pada penelitian ini didapatkan pada kedua kelompok perlakuan subjek berjenis kelamin perempuan lebih banyak daripada laki-laki (Tabel 1). Berdasarkan usia, subjek berumur 10 tahun pada kedua kelompok perlakuan lebih banyak dibandingkan dengan subjek berumur 11 tahun (Tabel 2).

Data pada Tabel 3 menunjukkan bahwa jumlah skor pre-test pada item pertanyaan nomor $1,2,3$, 4, dan 5 lebih tinggi dibandingkan jumlah skor pre-test pada item pertanyaan nomor $6,7,8,9$, dan 10. Hal ini menunjukkan bahwa siswa di SDN Kolongan masih memiliki pengetahuan yang rendah tentang cara menyikat gigi yang baik dan benar, karena item pertanyaan nomor $6,7,8,9$, dan 10 berisi pertanyaan tentang cara menyikat gigi yang 
baik dan benar. Tabel 3 juga menunjukkan bahwa terdapat peningkatan jumlah total skor hasil pengukuran tingkat pengetahuan anak dari pre-test ke post-test pada pemberian PKG menggunakan media video maupun menggunakan media flip chart. Keadaan ini menunjukkan bahwa pemberian PKG menggunakan media video dan media flip chart mampu meningkatkan pengetahuan anak tentang kesehatan gigi dan mulut.

Tabel 4 menunjukkan nilai $p$ (signifikansi) pada uji normalitas menggunakan Shapiro-Wilk. Nilai signifykansi sebelum diberikan PKG menggunakan media video (pre-test) yaitu 0,004 dan sesudah diberikan PKG (post-test) menggunakan media video yaitu 0,002 . Hasil yang diperoleh menunjukkan bahwa data tidak terdistribusi secara normal dan dilanjutkan dengan uji alternatif tberpasangan Wilcoxon.

Berdasarkan hasil uji Wilcoxon (Tabel 6) didapatkan nilai signifikansi sebelum (pre-test) dan sesudah (post-test) diberikan PKG menggunakan media video ialah 0,000. Data ini menunjukkan adanya perbedaan nilai hasil pengukuran tingkat pengetahuan sebelum dan sesudah diberikan PKG menggunakan media video $(p<0,05)$. Dengan demikian terjadi peningkatan bermakna dari nilai pre-test hasil pengukuran tingkat pengetahuan ke nilai post-test, yang berarti PKG menggunakan media video efektif dalam meningkatkan tingkat pengetahuan anak. Hasil ini sebanding dengan penelitian yang dilakukan Nurfalah $^{7}$ yang menunjukkan bahwa media video efektif dalam meningkatkan pengetahuan penyikatan gigi pada anak usia 9-12 tahun di SDN Keraton 7 Martaputra. $^{7}$

Pemanfaatan media video dalam pembelajaran dapat memberikan pengalaman belajar yang lebih lengkap, jelas, variatif, menarik serta menyenangkan. ${ }^{8}$ Media video termasuk dalam media pendidikan elektronik yang mempunyai kelebihan seperti mengikutsertakan banyak panca indera sehingga lebih mudah dipahami, lebih menarik karena ada suara dan gambar bergerak, bertatap muka, penyajian dapat dikendalikan, jangkauan relatif lebih besar, dan sebagai alat diskusi dan dapat diulang-ulang. ${ }^{9}$ Penggunaaan media video harus memiliki media pendukung elektronik seperti infocus, laptop, ataupun pemutar video, serta tentunya diperlukan aliran listrik pada penggunaannya. Media video juga bisa dimanfaatkan untuk hampir semua topik, model-model pembelajaran, dan setiap ranah kognitif, afektif, dan psikomotorik. Secara kognitif dengan melihat video dapat memperkuat pemahaman siswa terhadap materi ajar sebelum ataupun sesudah membaca sebuah materi ajar. Pada ranah afektif, video dapat memperkuat siswa dalam merasakan unsur emosi dan penyikapan dari pembelajaran yang efektif. Pada ranah psikomotorik, video memiliki keunggulan dalam memperlihatkan bagaimana sesuatu bekerja, video pembelajaran yang merekam kegiatan motorik/ gerak dapat memberikan kesempatan pada siswa untuk mengamati dan mengevaluasi kembali kegiatan tersebut. ${ }^{10}$

Tabel 5 menunjukkan nilai $p$ (signifikansi) pada uji normalitas menggunakan uji Shapiro-Wilk. Nilai signifikan sebelum diberikan PKG menggunakan media flip chart (pre-test) yaitu 0,006 dan sesudah diberikan PKG menggunakan media flip chart (post-test) yaitu 0,002. Hasil yang diperoleh menunjukkan bahwa data tidak terdistribusi normal $(\mathrm{p}<0,05)$ dan dilanjutkan dengan uji alternatif t-berpasangan Wilcoxon.

Berdasarkan hasil uji Wilcoxon (Tabel 7) didapatkan nilai signifikansi sebelum dan sesudah diberikan PKG menggunakan media flip chart sebesar 0,000. Data ini menunjukkan terdapat perbedaan nilai hasil pengukuran tingkat pengetahuan anak sebelum dan sesudah diberikan PKG menggunakan media flip chart $(\mathrm{p}<0,05)$. Oleh karena itu dapat dikatakan bahwa pemberian PKG menggunakan media flip chart efektif dalam meningkatkan tingkat pengetahuan anak. Hasil ini sebanding dengan penelitian yang dilakukan Nurhidayat $^{11}$ yang menunjukkan bahwa 
media flipchart sebagai kelompok kontrol efektif dalam meningkatkan pengetahuan kesehatan gigi dan mulut pada siswa di SDN Sukorejo.

Flip chart adalah salah satu media cetakan yang sederhana dan efektif. Flip chart terdiri dari lembaran-lembaran kertas yang dibundel menjadi satu dengan jilid ring sehingga dapat dibalikkan, yang berisi pesan dan diterangkan dengan gambar yang menjelaskan suatu topik secara cukup rinci. Setiap topik bahasan tertentu selalu terdiri dari 2 halaman, satu halaman bergambar dengan teks terbatas menghadap ke arah peserta sedangkan halaman yang menghadap fasilitator berisikan informasi kunci dan pertanyaan diskusi yang menjadi acuan pembahasan topik tersebut. Pemberian pendidikan kesehatan menggunakan media flip chart ini biasanya disertai dengan metode ceramah. ${ }^{12}$

Hasil uji Mann-Whitney (Tabel 8) menunjukkan adanya perbedaan yang signifikan selisih jumlah skor antara pemberian PKG menggunakan media video dan media flip chart dalam meningkatkan pengetahuan anak $(p=0,007)$. Data ini juga menunjukkan bahwa peningkatan tingkat pengetahuan anak pada kelompok yang diberikan PKG menggunakan media video lebih besar dibandingkan pada kelompok flip chart, yang ditunjukkan melalui nilai rerata selisih kelompok media video yaitu sebesar 38,12 sedangkan pada kelompok media flip chart hanya sebesar 26,88 . Hal ini dikarenakan media video memiliki kelebihan yaitu dapat menstimulasi efek gerak sehingga terlihat lebih menarik dan lebih mudah merangsang pemahaman siswa secara kognitif, afektif, dan psikomotorik, meskipun media video dan media flip chart yang disertai metode ceramah mempunyai tingkatan konkret yang sama dalam teori kerucut pengalaman Edgar Dale. Kedua media pendidikan ini melibatkan indera pendengaran dan indera penglihatan sehingga orang dapat mengingat $50 \%$ dari apa yang dilihat dan yang didengar. Selain itu, jangkauan pemberian PKG menggunakan media video relatif lebih besar dibandingkan media flip chart. $^{11}$

Pemanfaatan media pendidikan dalam promosi kesehatan tentunya untuk memperjelas penyajian pesan agar tidak terlalu bersifat verbalistik. Media pendidikan kesehatan juga diharapkan dapat membuat pengajaran lebih menarik perhatian sasaran pendidikan sehingga menumbuhkan motivasi belajar. Selain itu media pendidikan juga dapat mempermudah penyampaian materi pendidikan oleh para pendidik khususnya pada PKG. Beberapa prinsip dalam pemilihan media pendidikan juga harus diperhatikan seperti media yang dipilih harus disesuaikan dengan materi yang akan disampaikan; pendidik harus memahami ciri-ciri media sehingga antara media dan metode yang digunakan sesuai; kesesuaian media yang digunakan dengan kelompok sasaran; serta kelengkapan media sehingga dapat memberikan persepsi yang lebih baik kepada sasaran pendidikan. ${ }^{5}$

Hasil penelitian ini sebanding dengan penelitian yang dilakukan Megawati et al. ${ }^{13}$ tentang pengaruh pendidikan kesehatan tentang persalinan dengan audio visual dan lembar balik terhadap kecemasan pada ibu hamil trimester 3 yang mendapatkan bahwa media audio visual lebih efektif dibandingkan media flip chart dalam menurunkan tingkat kecemasan pada ibu hamil. Hasil yang sama juga diperoleh Kumboyono $^{14}$ yang meneliti tentang perbedaan efek penyuluhan kesehatan menggunakan media cetak dengan media audio visual terhadap peningkatan pengetahuan pasien tuberkulosis. Didapatkan bahwa penyuluhan kesehatan menggunakan media audio visual lebih baik daripada penyuluhan kesehatan menggunakan media cetak yang dilihat dari nilai rata-rata media audio visual lebih tinggi yaitu 23,8 dibandingkan dengan media cetak yaitu 22,0 dengan nilai $p$ (signifikansi) hasil uji $t$ independent 0,009 $(\mathrm{p}<0,05)$.

\section{SIMPULAN}

Dari hasil penelitian terhadap siswa SDN Kolongan yang berusia 10-11 tahun 
dapat disimpulkan bahwa:

1. PKG menggunakan media video dan media flip chart meningkatkan pengetahuan kesehatan gigi dan mulut anak secara bermakna

2. PKG menggunakan media video lebih efektif secara bermakna dalam meningkatkan pengetahuan kesehatan gigi dan mulut anak dibandingkan PKG menggunakan media flip chart

\section{SARAN}

Perlu dilakukan penelitian sejenis dengan menggunakan media pendidikan kesehatan yang berbeda atau dengan menambahkan media pendidikan kesehatan yang lain sebagai pembanding sehingga bisa diketahui jenis media yang paling efektif untuk membantu penyampaian informasi lewat pendidikan kesehatan.

\section{DAFTAR PUSTAKA}

1. Putri A. Pentingnya menjaga kesehatan gigi dan mulut. [cited: Maret 2016]. Available from: URL: https://independent.academia.edu/ AnastasiaPutri\}

2. Himakagi's Weblog. Pentingnya kesehatan gigi dan mulut anak. [cited: Maret 2016]. Available from: URL: https://himakagi.wordpress.com/penti ngnya-kesehatan-gigi-dan-mulutanak/\}

3. Pusat Data dan Informasi Kementrian Kesehatan RI. Situasi kesehatan gigi dan Mulut. Jakarta, 2014.

4. Notoatmodjo S. Ilmu Kesehatan Masyarakat. Jakarta: Rineka Cipta. 2003; p. 108-12.

5. Suiraoka IP, Supariasa ID.N. Media Pendidikan Kesehatan. Yogyakarta: Graha Ilmu, 2012; p. 5-7.

6. Tan CX. Perbandingan efektivitas metode pengajaran cara menyikat gigi terhadap penurunan indeks plak pada anak usia 6-11 tahun di sekolah Bodhicitta [Skripsi]. Medan: Universitas Sumatera Utara; 2010.

7. Nurfalah A, Yuniarrahmah E, Aspriyanto D. Efektifitas metode peragaan dan metode video terhadap pengetahuan penyikatan gigi pada anak usia 9-12 tahun di SDN Keraton 7 Martaputra. Dentino. 2014;II(2).

8. Susilana R, Riyana C. Media Pembelajaran Hakikat, Pengembangan, Pemanfaatan, dan Penilaian. Bandung: Wacana Prima, 2009; p. 9-11.

9. Notoatmodjo, S. Promosi Kesehatan Teori dan Aplikasinya. Jakarta: Rineka Cipta, 2010; p. 26-34.

10.Anderson RH. Pemilihan dan Pengembangan Media untuk Pembelajaran (terjemahan Yusufhadi Miarso, et al). Jakarta: Raja Grafindo Persada, 1994.

11.Nurhidayat $O$, Eram Tunggul $P$, Wahyono B. Perbandingan media power point dengan flipchart dalam meningkatkan pengetahuan kesehatan gigi dan mulut. Unnes Journal of Public Health. 2012;1(1).

12.Dirjen PPM \& PL. Panduan penggunaan media penyuluhan. Jakarta: Departemen Kesehatan RI, 2003.

13.Megawati, Safitri W, Fitriana Nur R. Pengaruh pendidikan kesehatan tentang persalinan dengan audio visual lembar balik terhadap kecemasan pada ibu hamil trimester 3 di Klinik Margo Husodo Gondang Sragen [Skripsi]. Surakarta: Stikes Kusuma Husada; 2014.

14.Kumboyono. Perbedaan efek penyuluhan kesehatan menggunakan media cetak dengan media audio visual terhadap peningkatan pengetahuan pasien tuberkulosis. Jurnal Ilmiah Kesehatan Keperawatan. 2011;7(1). 